\title{
Infância, gerações e temporalidades: experiências de crianças e professoras em diálogo
}

\author{
Raquel Gonçalves Salgado \\ Universidade Federal de Mato Grosso
}

\section{Resumo}

0 artigo tem como objetivo discutir como crianças e professoras significam mutuamente suas experiências de infância. A pesquisa situa-se no campo dos estudos da infância. Grupos de discussão sobre diversas experiências de infância, entre crianças e professoras de turmas de educação infantil, realizados em uma brinquedoteca universitária, consistem em estratégias metodológicas. Entre as professoras, há uma tendência em valorar as experiências atuais da infância como dissonantes de um ideal que se perdeu no tempo. As crianças, por outro lado, trazem a tecnologia e o consumo como marcas de suas experiências, questões que precisam ser contempladas na agenda da educação contemporânea.

Palavras-chave: Infância. Relações intergeracionais. Experiências. Contemporaneidade. 


\section{Childhood, generations and temporalities: children's and teachers' experiences in dialogue}

The aim of this article is to discuss how children and teachers mutually signify their childhood experiences. The study is included in the field of childhood studies. Discussion groups on diverse childhood experiences, between preschool children and teachers, held in a university toy library, are methodological strategies. Among the teachers, there is a tendency to value current childhood experiences as dissonant from an ideal lost in time. The children, on the other hand, mention technology and consumption as hallmarks of their experiences, matters that must be included in the agenda of contemporary education.

Keywords: Childhood. Intergenerational relations. Experiences. Contemporaneity.

\section{Infancia, generaciones y temporalidades: experiencias de niños y profesoras en diálogo}

El artículo tiene como objetivo discutir cómo niños y profesoras significan mutuamente sus experiencias de infancia. La investigación se sitúa en el campo de los estudios de la infancia. Grupos de discusión sobre diversas experiencias de infancia, entre niños y profesoras de educación infantil, en una ludoteca universitaria, consisten en estrategias metodológicas. Entre las profesoras, hay una tendencia a valorar las experiencias actuales de la infancia como disonantes de un ideal que se perdió en el tiempo. Los niños, por otro lado, traen la tecnología y el consumo como marcas de sus experiencias, las cuales necesitan ser contempladas en la agenda de la educación contemporánea.

Palabras clave: Infancia. Relaciones intergeneracionales. Experiencia. Contemporaneidad. 


\section{A pesquisa com crianças e professoras: a perspectiva intergeracional, seus recortes e percursos metodológicos}

São cada vez mais nítidos os desencontros e descompassos entre os modos como as crianças têm se manifestado nas mais diversas situações sociais, marcados por suas atitudes, conhecimentos e valores, e as expectativas que os adultos têm a respeito delas. Isto se aguça na esfera da educação, espaço social em que as novas gerações precisam se apropriar de conhecimentos que fazem parte do acervo cultural, com o objetivo de renová-los.

As imagens da infância tecidas historicamente apresentam-nos uma criança inocente e imaculada, que durante séculos - mais precisamente desde o século XVII -, como analisa Ariès (1981), vem se constituindo como um dos importantes pilares para a consolidação da família e da escola na modernidade. Essas imagens, no cenário contemporâneo, têm sido abaladas. Não mais se mantêm intactas quando confrontadas com as crianças concretas, a cada dia mais imersas em uma cultura que thes oferece uma diversidade de referências simbólicas, materializadas em objetos, produtos e informações, que têm provocado alterações significativas nos seus modos de agir, pensar e se relacionar com a cultura. Essas transformações subjetivas desestabilizam o princípio da inocência, como atributo que define a criança, ao desenharem outras imagens da infância, que, no espelho da cultura e da vida social, refratam aquelas consolidadas séculos atrás.

0 esmaecimento de fronteiras entre a infância e a vida adulta sinaliza as mudanças nas relações entre crianças e adultos, presentes em diversas cenas da vida contemporânea (Postman, 1999). Tecnologias, objetos culturais, informações, consumo estão cotidianamente interpelando esses sujeitos e mantendo próximas suas expectativas, ideais, valores e desejos.

Diante desse panorama de transformações, este artigo origina-se de questões postas no âmbito de uma pesquisa que se propõe a discutir, por um lado, os modos como as professoras significam as experiências, os valores e os saberes que as crianças têm produzido e revelado como próprios de seu tempo de vida; e, por outro, como estas últimas interpretam as experiências de infância narradas por suas professoras. Tal propósito justifica-se por duas razões: a primeira diz respeito à consideração da infância como uma categoria geracional de caráter relacional, dada a impossibilidade de compreendê-la fora da relação alteritária com a idade adulta; a segunda está relacionada ao fato de trazer à tona as tensões entre as imagens da infância produzidas historicamente e encarnadas em valores que atravessam os discursos e as práticas das professoras e o que elas identificam nos modos de ser e agir das crianças hoje como aspectos singulares da infância na contemporaneidade. 
A pesquisa situa-se no campo dos estudos da infância, que se propõem a interrogar a sociedade a partir da infância, entendida como categoria geracional em oposição à ideia de estado transitório para a vida adulta e se pautam, no âmbito deste artigo, nas reflexões de Sarmento (2008) e Qvortrup (2010).

No tocante à metodologia, a pesquisa assume um caráter de intervenção por instaurar espaços de discussão entre crianças e professoras sobre diversas experiências de infância - as que hoje se fazem presentes na vida das crianças e as que marcaram a história das professoras. Nessa perspectiva, os sujeitos envolvidos na pesquisa não são apenas informantes, posto que constroem conhecimentos e refletem sobre suas próprias concepções, valores e experiências. (Castro, 2008; Jobim e Souza; Salgado, 2008)

O contexto da pesquisa é uma brinquedoteca universitária, localizada no campus de Rondonópolis da Universidade Federal de Mato Grosso (UFMT), que vem atendendo, desde 2008, escolas de educação infantil da rede pública desse município. Sendo assim, desta pesquisa participaram três turmas do segundo agrupamento da educação infantil, compostas por crianças na faixa etária de 5 a 6 anos e suas respectivas professoras, com idades entre 40 e 50 anos, que atuam no magistério há entre 13 e 20 anos e na educação infantil entre 6 e 16 anos.

Como uma das estratégias metodológicas, temos a realização de grupos de discussão com as crianças e as professoras, organizados sob a forma de oficinas, como forma de suscitar diálogos voltados para questões relacionadas a diversas experiências de infância.

0 grupo de discussão que aqui se pretende analisar partiu da elaboração de um "livro", produzido por cada professora, sobre os acontecimentos marcantes da infância. Com ilustrações, desenhos, escritas, fotos e colagens, cada livro é lido para o grupo de crianças (turmal e em seguida discutido por nós, crianças, professoras e pesquisadoras, sujeitos de gerações distintas, com histórias e experiências às vezes próximas, outras vezes muito distantes. Nesses diálogos, comparamos, avaliamos e discutimos as diversas infâncias - as de tempos passados, que remetem às histórias das professoras; e as atuais, que dizem respeito ao que as crianças estão vivendo na cultura de seu tempo.

Após os encontros entre crianças e professoras na brinquedoteca, organizamos uma roda de conversa, da qual participaram apenas as professoras, as quais foram convidadas a refletir e discutir questões suscitadas a partir da apresentação de excertos dos diálogos estabelecidos com as crianças nos grupos de discussão. Além disso, entrevistamos as professoras sobre as suas experiências de infância, com o propósito de compreender como elas significam os modos de ser e agir das crianças com quem atuam. 


\section{Geração e experiência na relação entre infância e vida adulta}

Como afirmamos antes, partimos de uma compreensão de infância, fundamentada nos estudos da infância, como uma categoria social e geracional, que assume lugar relevante na análise dos processos de estratificação social e na construção das relações sociais (Sarmento, 2008). Além disso, a infância não pode ser entendida fora da relação com a vida adulta, configurando-se também como uma categoria de caráter relacional.

Para abordar o conceito de geração, é inevitável recorrer ao trabalho de Karl Mannheim (1982 [1952]), na primeira metade do século XX. Para o sociólogo, a geração não se define apenas por um grupo de pessoas que compartilham a mesma idade, mas pelo fato de elas terem em comum uma mesma situação sóciohistórica, constituída por bens simbólicos e materiais presentes em uma cultura específica. Nessa visada, o sentido de pertença a uma coletividade é o que confere sustentação ao conceito de geração. (Tomizaki, 2010)

Entretanto, essa consciência comum, que define e entrelaça sujeitos de uma mesma geração, não se manifesta de modo uniforme para todos. Para Mannheim (1982 [1952], p. 92), há diferentes níveis de participação no âmbito da geração, desde a situação de geração, caracterizada fundamentalmente pela partilha do tempo histórico, em que a participação nos rumos que toma e em seu destino aparece apenas como possibilidade, até a unidade de geração, na qual são construídos vínculos entre os sujeitos que os implicam e enredam mutuamente no seu destino.

0 rejuvenescimento da sociedade é outra marca importante que a geração deixa. Na perspectiva de Mannheim (1982 [1952]), esse fenômeno implica muito mais a composição de novas experiências pelos mais novos a partir da herança cultural transmitida pelos mais velhos do que o repasse de um repertório cultural acumulado às novas gerações, no sentido de manter o status quo. Uma sociedade apenas se mantém viva e dinâmica com o nascimento de pessoas, que inevitavelmente devem alterar os quadros provisoriamente estáveis da vida social, trazendo perdas indispensáveis e necessárias para o que se consolida como patrimônio cultural. Nessa lógica, confrontos intergeracionais não podem deixar de acontecer na história da sociedade humana, uma vez que, como argumenta Mannheim (1982 [1952]), as gerações estão em interações permanentes e, nelas, não são apenas os mais velhos que educam os jovens, mas também os jovens educam os mais velhos.

Estamos vivendo num momento histórico fortemente marcado por esses confrontos intergeracionais: crianças que não mais se reconhecem como inocentes e desafiam a tradicional demarcação do tempo da infância ao se apropriarem de 
signos da cultura midiática que devastam as fronteiras etárias; crianças que, com canções, danças, roupas, objetos e informações, atestam competências para participar de uma cultura antes definida como exclusiva da vida adulta e assim vão compondo outros sentidos para a infância; crianças e adultos, ao mesmo tempo, próximos e distantes, confrontando-se com imagens da infância que há muito já não correspondem às suas relações e experiências cotidianas; fronteiras rígidas que separam crianças e adultos vão se tornando instáveis, a ponto de não mais se sustentarem. Diante dessas cenas, perguntamo-nos: com que criança estamos dialogando? Como nós, adultos e educadores, estamos assimilando as experiências que as crianças têm construído? Afinal, quem é essa criança?

Na esteira da sociologia da infância, campo de conhecimento no qual a criança é vista como agente social e produtora de cultura (Qvortrup, 2010), não há como entendê-la como sujeito destituído de experiências. Não é pouco comum conservarmos ainda a ideia de que a experiência cabe àqueles que já percorreram uma trajetória de vida, como se fosse um acervo que apenas se compõe à medida que, no decorrer dos anos de vida, acumulamos saberes, práticas e histórias. Nesse entendimento, às crianças está reservado o cabedal de experiências apenas quando saírem da infância, já que por sua curta trajetória de vida não poderiam ser autorizadas a se apresentarem e manifestarem como sujeitos de experiência.

Como afirma Walter Benjamin (1984, p. 23, grifo do autor), “a máscara do adulto chama-se "experiência"', evangelho do filisteu - personagem que, no texto do filósofo, representa o adulto ou as gerações mais velhas -, cuja mensagem são as experiências acumuladas ao longo de seus anos, que se consolidam como a verdade sobre a vida: "Assim é a vida, dizem os adultos, isso eles experimentaram". (Benjamin, 1984, p. 23)

Na contramão da experiência como acervo acumulado pelos anos, Larrosa (2002, p. 21) define-a como "o que nos passa, o que nos acontece, o que nos toca”. Nesse sentido, subjetiva a experiência ao situá-la como acontecimento que nos altera e por isso nos constitui, independentemente dos anos acumulados ou de seu reconhecimento ou validade externos. A experiência, nessa visada, vale por aquilo que provoca no sujeito que a vive, seja criança, jovem, adulto ou velho. Como afirma Larrosa (2002, p. 25), ela é a trajetória da existência de um ser, que não se define por uma razão ou essência, mas por sua singularidade e contingência. Nessa lógica da diferença, da pluralidade e da heterogeneidade, infância e experiência não são antagônicas. Ao contrário, marcam também esse tempo de vida experiências singulares e legítimas, cujo fundamento e sentido não podem estar fora da vida infantil, como se aguardassem um telos ideal do existir humano, alcançado na suposta maturidade. As crianças são, assim, sujeitos de experiência tão legítimos quanto os adultos ou outras categorias etárias. Suas 
experiências não são a trajetória até uma meta prevista, conduzida por um destino que se conhece de antemão. (Larossa, 2002, p. 28)

Benjamin (1985), ao refletir sobre a vida moderna na primeira metade do século XX, já lamentava o declínio da experiência em detrimento da informação, impulsionada pelos meios de comunicação de massa. Se a arte de narrar está em vias de extinção e a experiência é a matéria-prima da narrativa, declara o filósofo, logo a capacidade de intercambiar experiências desaparece gradativamente. A experiência é a fonte de onde brota a narrativa. Cada vez mais rara, a arte de narrar tem sido substituída pela informação, para a qual os fatos já devem vir acompanhados por explicações objetivas e precisas. Enquanto a narrativa está imersa na vida do narrador e, portanto, o que ela comunica é a experiência, a informação, na sua efemeridade, desumaniza o fato ao descrevê-lo sem os rastros de quem o vive. (Benjamin, 1985)

Outra dimensão da narrativa que aqui ganha importância é a das experiências pretéritas da infância no tempo presente do adulto e que, portanto, se dá na tensa relação do passado com o presente. Embora as professoras tenham sido convidadas a lembrar de seus tempos de infância, os modos como essas narrativas foram construídas não se configuraram como autobiografias propriamente ditas, mas como extratos de lembranças de suas vidas de criança, que remeteram a eventos específicos eleitos por elas como aqueles pelos quais as crianças poderiam se interessar, por exemplo: as brincadeiras e os brinquedos próprios de suas infâncias. Ainda assim, narrar esses eventos implica sempre uma construção de si e dos modos como o "eu" que narra se vê no presente da narrativa. Gagnebin (1994) reporta-se às mônadas de Benjamin como imagens da memória, nas quais o "eu” que se diz não se lembra de si tal como foi ou viveu; mas, nessa lembrança, a experiência da alteridade impõe-se ao trazer o outro que, no confronto do passado com o presente, jamais é idêntico a si mesmo.

Nesse jogo do passado com o presente, entre a memória das crianças que foram e as crianças com as quais se deparam hoje, as professoras constroem em suas narrativas imagens de uma infância que as cenas da vida contemporânea parecem não querer mais retratar. Imagens essas que, aos poucos, vão se estilhaçando diante das experiências das crianças na contemporaneidade. 0 passado também dialoga com o presente no instante em que essas imagens de infância atravessam as ações educativas que as professoras põem em prática em suas relações com as crianças, na expectativa de que tais representações carreguem a "essência" da infância. 


\section{As histórias de infância das professoras em diálogo com as experiências das crianças}

Narrar as suas experiências de infância: este é o desafio que lançamos às professoras participantes da pesquisa ao propormos que elas elaborassem um livro de suas infâncias, que, após lido, foi por nós - crianças, professoras e pesquisadoras - discutido. 0 que foi vivido nesses encontros intergeracionais, atravessados por diferentes experiências de infância, é o foco de nossa análise a partir de então.

Nos livros das três professoras, a vida na/da infância passa-se no contexto rural, onde o contato com a natureza aparece como uma forte marca de suas histórias: brincar debaixo de árvore, com os pés descalços na areia, na rua, com os amigos, os irmãos e os vizinhos até à noite; subir em árvore; tomar banho de rio, enfim, como nos conta a professora $M A^{1}$ :

Eu brincava com tudo que uma criança da zona rural brinca, balançava de cipó, tomava banho de rio, brincava com os animais também, os animais eram brinquedos. As minhas bonecas, bem, na época não tinha boneca, mas tinha aquele milho e aí eu aproveitava as bonequinhas do milho para serem minhas bonequinhas, e embrulhava com os trapos de pano que mamãe permitia que pegasse. Mas eu era muito brincalhona com meninos e apanhava muito por isso, então as brincadeiras eram levantar pipa, brincar de bolinha de gude, pular corda, bem, essas coisas. Mas eu apanhava muito porque queria brincar só com o que, segundo minha mãe, não era da minha alçada brincar. Subir em árvore, meu Deus, como eu subia em árvore!

A infância representa um tempo em que as experiências das crianças estão bem demarcadas em relação à vida adulta, em que o respeito pelos mais velhos, sobretudo os pais, ganha notoriedade. Esse respeito aparece principalmente por meio dos trabalhos domésticos, imputados pelos pais, como atividades próprias da infância, como o trecho do livro "A história de Anita", personagem criada por $\mathrm{Cl}$ para narrar a sua infância. Anita era uma menina que tinha 10 irmãos; todos eles trabalhavam no sítio para ajudar seus pais. Até Anita, que estava com 5 anos e nem ia à escola ainda, trabalhava cuidando de sua irmãzinha Aninha, de 2 anos de idade.

O brincar também assume relevância nas histórias de infância das professoras e caracteriza-se como uma atividade que depende da produção artesanal da

1. Por exigência do Comitê de Ética em Pesquisa e como forma de preservar a identidade dos sujeitos participantes da pesquisa, apresentamos aqui apenas as iniciais de seus nomes. 
criança. Por essa razão, os brinquedos são, na maioria das vezes, confeccionados por elas: bonecas de pano, de barro, de sabugo de milho; vaquinhas de bucha verde; bilboquê com latinha de extrato de tomate; outros brinquedos inventados com latas de óleo, como narra a professora MC: "Como nossos pais não tinham dinheiro para comprar brinquedos, se queríamos brincar, tínhamos que produzir reciclando lixo." Além disso, o brincar é também uma atividade compartilhada com os pares, que se realiza em espaços coletivos, como a rua.

$\mathrm{Na}$ contracorrente do mundo informacional e tecnológico, as professoras, como "camponesas sedentárias" - nas palavras de Benjamin (1985), uma das representações arcaicas daquele que tem experiências a narrar -, trazem à tona infâncias muito díspares daquelas que as crianças com as quais atuam estão vivendo. Confrontos de visões, valores, experiências, saudosismo de um tempo que parece não mais voltar, perplexidade e curiosidade diante das diferenças, às vezes radicais, que a vida alheia apresenta em relação à sua própria são alguns dos aspectos aqui discutidos a partir dos diálogos com as crianças e as professoras.

\section{Do mundo da fantasia à realidade nua e crua}

As crianças, a cada dia mais imersas nos modos de organização da sociedade e atentas aos requisitos que permitem nestes se inserir, estão se apropriando da vida social de forma mais pragmática, abrindo mão, às vezes, de conteúdos fantásticos, que, comumente, compõem ou compunham o imaginário da infância. Em outra pesquisa que analisa como as crianças significam as relações entre infância e poder, mediadas por textos midiáticos, discutimos o poder pragmático, como outra faceta do poder infantil que, ao contrário do poder mágico, atravessado pela fantasia e ficção, produz efeitos práticos e se aplica a diversas esferas cotidianas, como é o caso das relações estabelecidas com os adultos (Salgado, 2008). Isto, de certa forma, também é observado quando as crianças comentam um trecho da história de infância da professora MA ao narrar sobre as suas expectativas na noite de Natal.

Professora MA muda a página do desenho e aparece uma Árvore de Natal.

Pesquisadora: Olha só, o Natal!

Professora MA: Quando chegava o Natal, do dia 24 para o dia 25, a minha mãe falava que o Papai Noel vinha trazer um presente pra gente. Ela mandava a gente lavar os chinelinhos bem lavados e pôr atrás da porta, que aí o Papai Noel vinha à noite e deixava um presentinho para nós. E sabia que era verdade? No outro dia, quando a gente acordava, a gente ia lá atrás da porta para ver se tinha, e não é que tinha mesmo 
um presente?

R: Não era o Papai Noel que colocava.

Professora MA: Não era, mas ela falava para gente que era o Papai Noel que colocava.

R: Era só para vocês trabalharem.

(Risos).

Professora MA: Pois é, era só para gente trabalhar, lavar os chinelos, né?

F: Mas quem colocava os presentes lá? Sua mãe e seu pai?

Professora MA: Minha mãe e meu pai? Ué, não era o Papai Noel?!

Pesquisadora: Era isso que eu ia perguntar, não era o Papai Noel?

M: Era a mãe dela.

Professora MA: Mas, ela falava que era o Papai Noel. A gente acreditava.

Pesquisadora: Então, o $\mathrm{M}$ disse que era sua mãe.

GA: Não é. É o Papai Noel.

(Crianças começam a discutir entre si sobre quem colocava os presentes).

Pesquisadora: Afinal de contas, quem colocava os presentes?

Crianças: A mãe.

Professora MA: Era minha mãe e meu pai, né? Eles iam lá, compravam os presentes e guardavam e deixavam lá no dia de Natal.

Perplexa diante da desconstrução da ideia de Papai Noel como o "bom velhinho" que, nas noites de Natal, deixa secretamente debaixo da Árvore o presente que a criança tanto deseja, a professora tenta insistir na permanência de sua existência. Papai Noel, figura natalina emblemática que, há séculos, povoa o imaginário infantil, nos dias atuais, também não se mantém intacto. Para as crianças concretas do nosso tempo, o importante é quem compra os presentes. Estes sim são os sujeitos reais que, alvos de suas barganhas e negociações, realizam o ato derradeiro de posse da mercadoria que se transforma no presente de Natal.

No excerto abaixo, temos um diálogo retirado da roda de conversa com as professoras sobre o que foi produzido nos grupos de discussão.

Pesquisadora: Não, e aí? 0 que que aconteceu? 0 diálogo foi pra outro campo, né? Do Natal com Papai Noel pra um Natal em que pai e mãe compram presentes e colocam na Árvore de Natal.

Professora MA: Por que o diálogo toma esse rumo?

Professora $\mathrm{Cl}$ : Porque agora eles estão bem antenados, eles não acreditam mais.

Professora MA: É a realidade deles, né? Que eles estão vivendo.

Pesquisadora: E vocês acham que eles são mais realistas do que as crianças do passado, as crianças de hoje?

Professora MA: São. 
Professora $\mathrm{Cl}$ : Nós éramos mais sonhadoras, né?

Professora MA: É.

Professora $\mathrm{Cl}$ : A gente tinha esperança que de uma caixinha mágica ia surgir aquilo que a gente queria, por exemplo, uma boneca. Eu queria uma boneca loira de cabelos compridos, eu queria, então, no Natal era isso, se não era nesse Natal, se não veio, então, no outro Natal. Até que eu me dei conta que o Papai Noel não vinha trazer essa boneca pra mim.

Pesquisadora: E ela achava que era o Papai Noel mesmo? Isso com quantos anos?

Professora $\mathrm{Cl}$ : Ah!... Eu acho que eu sonhei muito até uns oito anos.

Quando minha mãe dizia assim: "Vai pegar uma espiga de milho que também tem cabelos loiros". Aí, eu brincava com aquela espiga de milho. "Mas, um dia eu vou ter minha boneca. Papai Noel vai trazer." Ela falava assim: "Não, Papai Noel tem muito o que fazer pra vim cá na roça trazer boneca pra você." “Ah! Então, tá bom, mas o dia que ele tiver tempo..."

Pesquisadora: Deixa eu perguntar uma coisa pra vocês: a que vocês acham que se deve esse realismo tão grande, tão marcante nas crianças hoje?

Professora $\mathrm{Cl}$ : Eu imagino que é porque eles vão juntos pra comprar, vão até pra escolher tem hora, né? Eles escolhem...

Como podemos observar, as professoras destacam os contrastes entre uma infância marcada pela esperança de que o sonho natalino com o brinquedo tão esperado um dia seria realizado e outra infância em que as crianças não mais sonham ou alimentam imaginariamente o tempo da espera por sua concretização. Ao contrário, percebem que as crianças conhecem os passos efetivos para obter o que desejam: vão às compras com os pais, escolhem o presente de Natal e, assim, o conquistam.

\section{Da infância artesanal à infância dos aparatos eletrônicos: é possível viver sem tecnologia?}

Da infância íntima com a natureza, destituída de aparatos eletrônicos, brinquedos industrializados, brincadeiras encerradas no ambiente doméstico ou individualizadas, para a infância do mundo tecnológico e do consumo, as crianças são convidadas a refletir sobre essas diferenças.

Pesquisadora: Em que época, então, era mais legal para ser criança? Na época da professora MA, que também é a época do pai do $R$, que é minha época. Antigamente. Então, em que época é mais legal ser criança, na época da professora MA ou hoje? 
(A maioria das crianças responde hoje. $\mathrm{R}$ e $\mathrm{G}$ respondem que é na época da professora MA).

Pesquisadora: Por que da professora MA?

R: Porque a gente nunca brinca na rua.

(As crianças concordam que brincar na rua é muito melhor do que hoje).

Pesquisadora: Então, devia ser legal brincar na rua, né? Não tinha tantos carros. E hoje? É legal ser criança hoje?

Crianças: É.

R: Por que é legal? 0 que tem de bom hoje que não tinha antes, que não tinha na época da professora MA?

D: Telefone.

M: Televisão.

Pesquisadora: Televisão já tinha naquela época, mas não era todo mundo que tinha.

F: Computador.

Pesquisadora: Telefone, televisão, computador, o que mais?

GA: Celular.

Pesquisadora: É, celular não tinha de jeito nenhum, né, professora MA?

Professora MA: É, não existia.

Pesquisadora: A gente nem sonhava com isso.

GA: Notebook.

Pesquisadora: Notebook, então! A gente nem imaginava.

S: E por que você não tinha notebook, tia?

Professora MA: É, porque não tinha na época.

S: E por que você não comprou?

Professora MA: Porque não existia, S.

É importante observar como as crianças avaliam suas experiências e as alheias, estabelecendo contrapontos em ambas. Se, por um lado, a infância ao ar livre - de brincar na rua - da professora se apresenta para elas como mais interessante, por outro, a ausência de tecnologias na vida de MA quando era criança causa um estranhamento que as desagrada, já que o "bom" da infância hoje é a presença da televisão, do celular, do computador, do notebook etc.

Para as professoras, a tecnologia também aparece como um significativo diferencial entre a infância de sua geração e a das crianças hoje, como revelam nas situações de entrevista e na roda de conversa.

0 acesso deles é mais fácil, porque antes a gente, nossa! Pra ter uma televisão! E o medo de estragar! E o medo de estragar! Não podia estar pegando a vontade. E hoje não. Eles dominam assim, melhor que o adulto, né? As crianças dominam. (Professora MA) 
... Infelizmente muito deles vivem sua infância - não digo essa classe nossa aqui, mas essa outra classe um pouco mais acima -, na frente dos computadores, na frente da televisão, eles deveriam brincar mais. Outra coisa que hoje em dia quase não tem, que são as brincadeiras. (Professora MC)

E outro fato que está aí também e que ajuda muito é os meios de comunicação, coisas na área da informática, jogos. Elas pegam um celular hoje, e se você coloca um celular na mão delas, elas aprendem primeiro que você. Elas fazem sem medo. Coloca um na mão nossa e outro na mão delas, elas vão ensinar para a gente tudo que faz, porque a gente não conseguiu aprender no mesmo tempo. Agora o ponto negativo é o que eu já falei. É a violência, estão muito abertos esses programas na televisão. Esse negócio de sexo assim, a sexualidade deles, está muito precoce, isso aí eu acho que está muito... Então, sai tudo isso, sabe, então, isso, sei lá, está difícil nessa parte, criança de cinco anos já sabendo fazer coisas que eu fui saber como fazia depois dos quinze. (Professora $\mathrm{MCl}$

As professoras admitem que o acesso das crianças às novas tecnologias potencializam conhecimentos que as de outrora não demonstravam. Estabelecem, ainda, distinções quanto aos modos de uso desses aparatos: enquanto os adultos temem manipulá-los, as crianças os dominam com destreza e segurança. Isto nos reporta aos estudos ${ }^{2}$ da relação entre infância e mídia, abordados por Buckingham (2000), que vão compor a vertente de celebração da presença da tecnologia digital na vida das crianças na contemporaneidade ao defenderem a existência de um distanciamento entre a geração de adultos e as mais jovens, no que se refere aos usos dessas tecnologias. Nessa perspectiva, enquanto as crianças são dotadas de competência e sabedoria para lidar com a tecnologia, os adultos são incompetentes e "tecnofóbicos"3 (Buckingham, 2000, p. 47), como é o caso das professoras.

Por outro lado, é também a tecnologia, na visão de uma das professoras, o fator que desvirtua a imagem da infância inocente, assumida como um valor entre elas. Desse modo, a tecnologia, como portal que abre acesso a diversas informações para as crianças, desenha outras experiências de infância, muito distintas da imagem secular e idealizada da infância, que, aos olhos da professora, são negativas. Sexo e violência aparecem como os conteúdos que maculam a imagem da infância que a professora gostaria ainda de encontrar viva nas experiências das crianças.

2. Tapscott, Papert, Katz e Rushkoff são alguns dos autores mencionados na obra de Buckingham (2000). 3. Tradução da palavra em inglês technofobes. 


\section{Da criança submissa à criança exigente: as demandas do consumo}

$\mathrm{Na}$ história de vida das professoras, as crianças e os adultos ocupavam lugares bem demarcados, definidos por fronteiras nítidas entre a infância e o mundo adulto: as crianças não participam dos assuntos compartilhados pelos adultos; 0 adulto ordena, a criança obedece.

Com certeza, até porque eu lembro que o meu pai, quando chegava um adulto, os compadres, e eles começavam a conversar sobre vendas de gado, de terra, coisas assim comuns da zona rural, né? E a gente ficava na sala e de repente queria interromper, ele falava assim: "Isso aqui é conversa de adulto, não é conversa de criança não." Essa palavra, pronto, acabou. A gente afastava-se daquela sala e não voltava até aquela visita ir embora. Por que já tinha dito o que era pra ser dito, era conversa de adulto.(Professora Cl)

Numa sociedade em que a cultura, a economia e as relações subjetivas têm se estruturado no consumo, não há mais lugar para a criança retratada nas infâncias das professoras, que, diante da impossibilidade financeira de comprar, se resigna e busca meios artesanais para obter o brinquedo: produzi-lo pode substituir a sua versão industrializada.

Como nossos pais não tinham dinheiro para comprar brinquedos, se queríamos brincar, tínhamos que produzir reciclando lixo. Fazíamos bonecas de barro, de sabugo de milho, vaquinhas de bucha verde, bonecas de espigas de milho etc. $E$ também bilboquê com latinha de extrato de tomate. (Professora MC)

O diálogo abaixo traz uma criança muito distinta daquela de outrora, quando provocada a comparar e refletir sobre o que fazer diante de uma experiência de infância afastada da possibilidade de consumir.

Pesquisadora: E se eles não comprassem nada, hein?! Se não comprassem as bonecas e os carrinhos? Como que seria?

ED: Falaria para eles comprar.

Pesquisadora: E se eles falassem assim: “Eu não tenho dinheiro, não dá para comprar boneca, carrinho". E aí? 0 que vocês iam falar para eles?

EV: Tem que trabalhar para ganhar dinheiro.

Pesquisadora: Mas vem cá: os pais têm que trabalhar para comprar brinquedos para as crianças? É isso?

Crianças: É! 
Pesquisadora: Todos os pais têm que fazer isso?

Crianças: É!

Pesquisadora: E os pais se disserem assim: "Eu hoje não posso comprar brinquedo para criança nenhuma".

L: Mas, tem que comprar brinquedo, mas também sandália, roupa, remédio quando a gente fica doente, shampoo...

Pesquisadora: J, mas se seu pai chegar e falar: "Eu não tenho mais dinheiro, não posso mais comprar brinquedo para você." E aí? 0 que você ia falar para ele?

J: Comprar.

Pesquisadora: Mas ele não tem mais dinheiro. Você vai ter que ficar sem o brinquedo. E aí?

$\mathrm{J}$ : la falar para trabalhar para comprar brinquedo.

Pesquisadora: Mesmo ele já trabalhando?! Você não pode ficar sem o brinquedo, não? $\mathrm{J}$ : la falar para comprar!

Pesquisadora: Dá para ficar sem comprar o brinquedo?

Crianças: Não!

Pesquisadora: Não dá, M?!

M: Não!

Pesquisadora: Dá para ficar sem brinquedo nenhum?

Criança: Não!

Pesquisadora: E se ficar sem brinquedo, o que vai acontecer com a criança?

L: Vai ter que brincar com outra coisa.

Pesquisadora: Vai ter que fazer que nem a professora MC?

L: É.

Professora MC: É. Vai ter que confeccionar o seu brinquedo.

Pesquisadora: Viu! Ela encontrou uma saída. Mas teve gente, né, M? Falou que não dava para ficar sem brinquedo. Por que $M$ ?

M: Porque sem brinquedo eu vou ficar emburrado.

Nas cenas cotidianas do nosso tempo, as crianças, interpeladas por signos que ensinam a consumir como forma de garantir a inserção social e passam a ser fundamentais para a constituição identitária, não podem mais acatar a ordem da precariedade material. 0 apelo torna-se indispensável e urgente. 0 grito diante da falta de ar, água e alimento, como forma de sobrevivência, em muito se assemelha às demandas da criança diante da impossibilidade de comprar, posto que este ato tem, também, se tornado indispensável para a sobrevivência em sociedade.

Consumir como um modo de ser e agir no mundo é, sem dúvida, uma das marcas de nossa trajetória na cultura contemporânea. Os objetos, alvos do consumo, há muito já não falam mais de si próprios, de suas utilidades e benefícios práticos, mas 
do que podem oferecer em termos de signos identitários (Sarlo, 1997). A infância não está fora desse mundo onde as coisas se comunicam com desejos e fantasias, despertando outros cada vez mais novos, e aparecem como signos de identidade e distinção. Como um dos alvos privilegiados da sociedade de consumo, a criança tem movimentado poderosas remessas de capital pelo mundo afora, sendo o pivô da criação de mercados e mercadorias exclusivamente dedicados a ela.

\section{Considerações}

A infância, como tempo de vida idealizado, idílico, de brincadeiras ao ar livre, de pés descalços e na terra, de contato com a natureza, de fazer os próprios brinquedos, de obediência aos mais velhos porque crianças não se misturam com adultos, reporta-se ao tempo das professoras, "camponesas sedentárias", cujas narrativas são tecidas por suas experiências singulares e, ao mesmo tempo, coletivas. Infância esta retratada por Casimiro de Abreu (1999), no poema "Meus oito anos", das saudades da aurora da vida que os anos não trazem mais, tempo do "despontar da existência", da alma que respira inocência, e que já não mais aparece como cena da nossa vida cotidiana e do convívio com as crianças.

Por outro lado, as crianças, com suas experiências atravessadas pelas tecnologias e pelo consumo, têm desenhado imagens bem distintas da infância saudosa de suas professoras: crianças que, com os pés fincados no mundo da economia globalizada, das relações sociais cada vez mais competitivas, não mais recorrem a entidades imaginárias para o cumprimento do que desejam - elas escolhem, exigem, compram -; crianças ávidas por informações e conhecimentos que rompem as fronteiras com o mundo adulto; crianças demandantes, que não se resignam facilmente diante da impossibilidade de ter.

As transformações no âmbito das experiências de infância da geração das professoras e da geração de crianças são óbvias, dadas as mudanças visíveis e aceleradas pelas quais temos passado desde a virada do século, no que diz respeito à economia, à cultura, às relações sociais, aos modos como os sujeitos têm se constituído. No entanto, essas transformações, embora percebidas e vividas, ainda não têm se traduzido em outros modos de pensar os sujeitos e as suas relações, sobretudo em se tratando da educação escolar. Educar e ensinar as crianças neste mundo, que há muito não se identifica com o paraíso perdido de "Meus oito anos", requer de professores e educadores das novas gerações a refração das imagens congeladas da infância a partir das imagens postas pelas crianças nos modos como elas têm se apropriado da cultura de seu tempo, construindo conhecimentos e valores que não podem ser descartados pelo processo educativo. Ao contrário, 
estes precisam estar contemplados na agenda de uma educação que se defina como ética e comprometida com a crítica da cultura.

Em se tratando especificamente da educação infantil, já que a dimensão ética é um de seus eixos importantes, faz-se indispensável compreender e intervir nos modos como as crianças têm pautado suas relações com os outros, cada vez mais, inspiradas em valores regidos pela lógica do consumo e da competitividade, que acarretam, em algumas situações, práticas discriminatórias e excludentes. Se considerarmos que a maioria das crianças que participaram da pesquisa em tela provém de famílias de classe média baixa, com poder aquisitivo limitado, podemos refletir sobre a intensidade desses valores como vetores de subjetivação desde a mais tenra infância, presentes na família e na escola, posto que, mesmo diante da impossibilidade de ter, condição social também vivida e narrada pela maioria das professoras, as crianças, imersas no pragmatismo da vida cotidiana e nos mundos tecnológicos, fazem dos apelos ao consumo os seus passaportes para a convivência social.

\section{Referências}

ABREU, Casimiro de. Primaveras. Porto Alegre: L\&PM, 1999.

ARIĖS, Philippe. História social da criança e da família. 2. ed. Rio de Janeiro: Editora Guanabara, 1981.

BENJAMIN, Walter. Reflexões: a criança, o brinquedo e a educação. São Paulo: Summus, 1984. p. 23-25.

BENJAMIN, Walter. Obras Escolhidas: magia e técnica, arte e política. 2. ed. v. 1. São Paulo: Brasiliense, 1985.

BUCKINGHAM, David. After the death of childhood: growing up in the age of electronic media. Cambridge: Polity Press, 2000.

CASTRO, Lucia Rabello de. Conhecer, transformar(-se) e aprender: pesquisando com crianças e jovens. In: CASTRO, Lucia Rabello de; BESSET, Vera Lopes (orgs). Pesquisa-intervenção na infância e juventude. Rio de Janeiro: Faperj, 2008. p. 21-42. GAGNEBIN, Jeanne Marie. História e narração em Walter Benjamin. São Paulo: Perspectiva: Fapesp; Campinas, SP: Editora da Universidade Estadual de Campinas, 1994.

JOBIM E SOUZA, Solange; SALGADO, Raquel Gonçalves. Mikhail Bakhtin e a ética das imagens nos estudos da infância: uma proposta de pesquisa-intervenção. In: CASTRO, Lucia Rabello de; BESSET, Vera Lopes (Orgs.). Pesquisa-intervenção na infância e juventude. Rio de Janeiro: FAPERJ, 2008. p. 490-513.

LARROSA, Jorge Bondía. Notas sobre a experiência e o saber de experiência. 
Revista Brasileira de Educação, Rio de Janeiro, Anped, n. 19, p. 20-28, jan.-abr., 2002.

MANNHEIM, Karl. (1952). O problema sociológico das gerações. In: FORACCHI, Marialice Mencarini. (Org.). Karl Mannheim: Sociologia. São Paulo: Ática, 1982. p. 67-95.

POSTMAN, Neil. O desaparecimento da infância. Rio de Janeiro: Graphia, 1999.

QVORTRUP, Jens. A infância enquanto categoria estrutural. Educação e Pesquisa, São Paulo, v. 36, n. 2, p. 631-643, mai.-ago., 2010.

SALGADO, Raquel Gonçalves. Entre a ficção e a realidade: as facetas do poder infantil na cultura contemporânea. In: OSWALD, Maria Luiza Bastos; PEREIRA, Rita Marisa Ribes. Infância e juventude: narrativas contemporâneas. Petrópolis, RJ: DP et Alii; Rio de Janeiro: Faperj, 2008. p. 87-105.

SARLO, Beatriz. Cenas da vida pós-moderna: Intelectuais, arte e videocultura na Argentina. Rio de Janeiro: Editora da UFRJ, 1997.

SARMENTO, Manuel Jacinto. Sociologia da infância: correntes e confluências. In: SARMENTO, Manuel Jacinto; GOUVEIA, Maria Cristina Soares de. (Orgs.). Estudos da infância: educação e práticas sociais. Petrópolis, RJ: Vozes, 2008. p. 17-39. TOMIZAKI, Kimi. Transmitir e herdar: o estudo dos fenômenos educativos em uma perspectiva intergeracional. Revista Educação e Sociedade, Campinas, Cedes, v. 31, n. 111, p. 327-346, abr.-jun., 2010.

Recebido em agosto de 2013

Aprovado em dezembro de 2013

Raquel Gonçalves Salgado é doutora em Psicologia pela Pontifícia Universidade Católica do Rio de Janeiro (PUC-RJ) e professora associada do Programa de Pós-Graduação em Educação da Universidade Federal de Mato Grosso. E-mail: ramidanaterra.com.br. 